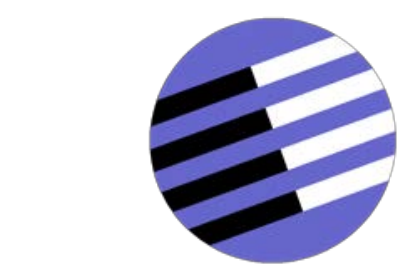

GOVERNANCE AND THE EFFICIENCY

OF ECONOMIC SYSTEMS

G E S Y

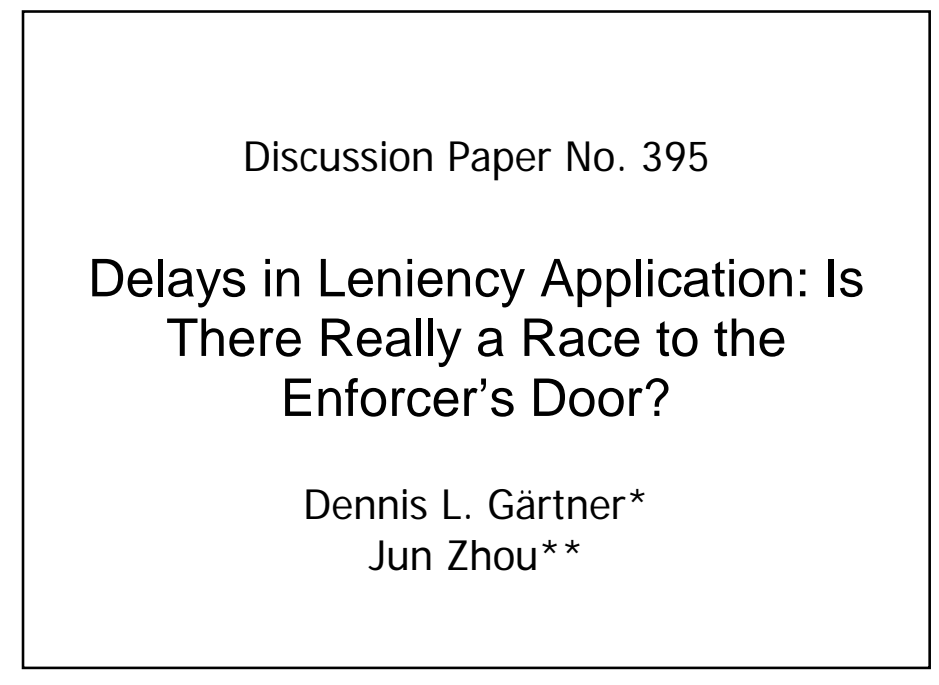

* University of Bonn

** University of Bonn

December 2012

Financial support from the Deutsche Forschungsgemeinschaft through SFB/TR 15 is gratefully acknowledged. 


\title{
Delays in Leniency Application: \\ Is There Really a Race to the Enforcer's Door?*
}

\author{
Dennis L. Gärtner and Jun Zhou ${ }^{\dagger}$ \\ First version June 2012, Revised November 2012
}

\begin{abstract}
This paper studies cartels' strategic behavior in delaying leniency applications, a take-up decision that has been ignored in the previous literature. Using European Commission decisions issued over a 16-year span, we show, contrary to common beliefs and the existing literature, that conspirators often apply for leniency long after a cartel collapses. We estimate hazard and probit models to study the determinants of leniency-application delays. Statistical tests find that delays are symmetrically affected by antitrust policies and macroeconomic fluctuations. Our results shed light on the design of enforcement programs against cartels and other forms of conspiracy. Journal of Economic Literature Classification Numbers: D43, K21, K42, L13.
\end{abstract}

Keywords: corporate leniency program, cartel, leniency application delays

\section{INTRODUCTION}

A LENIENCY PROGRAM grants cartel members who by their co-operation contribute to uncovering an illegal cartel immunity from or a reduction of government penalties. Such programs have become increasingly popular in many jurisdictions around the world (OECD 2002, 2003; Harrington 2011). Leniency programs are frequently described, by economists (e.g., Harrington 2008, 2011; Chang and Harrington 2010), ${ }^{1}$ antitrust authorities (Hammond 2001, 2004, 2010; Suurnäkki and Tierno Centella 2007; Kloub 2009) and legal practitioners (Baker \& McKenzie 2010; Willis 2011), as a "race": Cartel members rush to confess in order to beat their fellow conspirators to the enforcer's door. If the "race" were as close-run as theory and anecdote

\footnotetext{
*Support from the German Research Foundation through SFB TR 15 is gratefully acknowledged. We benefited from discussion with Jaap Abbring, Jan Boone, Eric van Damme and Joseph Harrington on this project. Any mistakes are our own.

†Send correspondence to: Jun Zhou; Email: okonom.bonn@gmail.com

${ }^{1}$ For instance, in Harrington (2008), when the probability that a competition authority discovers and successfully prosecutes a cartel is sufficiently high, cartel collapses and all firms race for leniency. Harrington refers to this as the "Race-to-the-Courthouse" effect.
} 
appear to suggest, one might be tempted to conclude, based on the fact that detection was infrequent prior to leniency introduction (Miller 2009; Hammond 2004), that leniency created distrust among conspirators, freed up investigatory resources that would be otherwise spent identifying the reported cartel (Kaplow and Shavell 1994; Buccirossi and Spagnolo 2005), and enhanced the authorities' detection capabilities. This paper explores the dynamic nature of leniency application. The main objectives are to document empirically that delayed applications are a relevant phenomenon, to understand the cause of delays, and to evaluate leniency programs' effectiveness in inducing whistle-blowing. The results have implications for market efficiency and enforcement efforts against cartels and other forms of organized crime.

One common feature of the game theoretical literature in this area has been the restrictive assumption that conspirators apply for leniency, once they decide to do so, as soon as a cartel collapses. The validity of this assumption will be tested here. The assumption might be unsatisfactory because first, it precludes an analysis of the pattern of leniency application over time and does not provide a framework for analyzing policies concerned with delays; second, application delays are empirically important: Over three quarters of the European Commission (hereafter "EC") leniency applications by first-in applicants took place not before but after a cartel collapses; Nearly 40 percent of the applications by first-in applicants postdated cartel dissolution by at least a year; More than half of the applications by first-in applicants arrived after the "dawn raids", by which time the EC was already aware of the cartels' existence. ${ }^{2}$ This salient empirical regularity suggests that standard computations of both the conspirators' incentive to denounce a cartel and the cartel-destabilizing effect provided by leniency may be biased.

This paper provides the first independent empirical analysis of leniency application delays, from the date that a cartel collapses, to the time that the first applicant reports the cartel, and up to the closure of an antitrust investigation. Much of our extant knowledge regarding the timing of leniency application comes from antitrust officials, who consistently laud the incentives that leniency programs create for conspirators to rapidly disclose hidden cartels:

The catch is that [immunity] is only available to the first one in the door ... the second firm and all of its culpable executives will be subject to full prosecution. This "winner-take-all" approach sets up a race ... (Scott D. Hammond 2001; US Department of Justice).

\footnotetext{
${ }^{2} \mathrm{~A}$ dawn raid is the first stage of an EC investigation where the EC's launches a surprise inspection at a company premise to recover evidence about possible infringements before the company destroys it.
} 
The rewards for self-reporting are too great, the consequences of getting caught too severe. The dynamic literally creates a race to be the first to the enforcer's office (Scott D. Hammond 2004; US Department of Justice).

The fact that the greatest protection, immunity from sanctions, is granted only to the first cartel member to report, induces strategic behavior ... hence creating conditions for a "race to the door" of a competition authority (Jindrich Kloub 2011; EC DG Competition).

The race-to-the prosecutor's-door mentality ... has successfully fueled leniency programs around the world (Ann O'Brien 2008; US Department of Justice). ${ }^{3}$

There are at least three reasons to view these statements with caution, although the latest empirical evidence seems to suggest that leniency programs in the U.S. and the E.U. may have the intended effects (Miller 2009; Zhou 2012a). First, to qualify for amnesty, firms need not report a cartel immediately upon leaving it. By holding off reporting when the other firms are currently doing so, a firm remains eligible but avoids attracting attention from antitrust authorities. Once the opportunity matures, the dead cartel can be evoked without increased antitrust surveillance; Second, because leniency is more powerful when firms fear that their accomplice will apply (Harrington 2011), antitrust authorities may have an incentive to cultivate tensions and distrust among the firms. Overstating the pace of whistle-blowing may be a way to achieve such an effect; Third, antitrust authorities in most of the jurisdictions (e.g., the U.S. Department of Justice (hereafter "DOJ")) keep strict confidentiality regarding the details of leniency applications (including among others, their dates). Although it is possible to draw inferences in some cases, more commonly the details (or even existence) of a leniency applicant is unknowable from publicly available data (Spratling 1999; Miller 2009). The potentially perverse incentives in combination with a lack of institutional transparency in most of the jurisdictions make a study such as ours particularly valuable.

We present evidence that leniency application delays are empirically relevant using a time series of EC cartel decisions issued between October 1996 and March 2012. The time series provides data on the dates of cartel dissolution and leniency application which allow us to form

\footnotetext{
${ }^{3}$ Hammond is the deputy assistant attorney general of the US Department of Justice and was director of criminal enforcement in 2000 and 2001. Kloub is a case handler in the cartel division of the EC DG Competition. O'Brien is senior counsel to the deputy assistant attorney general for criminal enforcement of the US Department of Justice.
} 
a relatively precise measure of application delays. We highlight the differences in delays across different leniency regimes.

Reduced form, semiparametric hazard models and probit models are used and compared to alternative approaches. The models test how changes in antitrust policies and macroeconomic conditions affect the length of leniency application delays. We are able to control for the manpower of EC Directorate-General for Competition, fine reductions, cartel duration and other factors that may influence applications. We find that the EC's new leniency expedites amnesty applications; and delays are shorter during recessions.

A full analysis of the problem of delayed leniency application would model jointly the cartel dissolution and the application decision. Such a model is beyond the scope of the current effort. The process of cartel dissolution is not uninteresting, but it is explored in detail elsewhere. ${ }^{4}$

Our results may have important policy implications. Cartels impede market efficiency and harm consumer welfare. Although most jurisdictions around the world treat hardcore cartels as "[t]he most serious ... violations of competition law" (OECD 2002b), the data analyzed here indicate that the EC discovered hardcore cartels in more than 50 distinct industries across four continents over the sample period. Our results suggest that standard computations of both a conspirator's incentive to apply for leniency and the destabilizing and deterrent effects provided by the leniency programs may be biased. Assuming that conspirators report a cartel as soon as the cartel ends overstates leniency's efficacy in enhancing detection and saving enforcement resources, as more than half of the applications by first-in applicants postdated the dawn raids. Moreover, we are not aware of any in-depth empirical analysis of this delay behavior.

The paper is organized as follows. In Section 2, we provide relevant institutional background on the leniency programs. We highlight the fact that leaving a cartel provides only a necessary, but not a sufficient, condition for applying for leniency. We briefly review the leniency program literature, emphasizing areas where realistic consideration of leniency-application behavior can affect analysis. Section 3 presents evidence that leniency application delays are empirically relevant. We use data from the EC to show that delays are frequent and, in many instances, long. Section 4 investigates determinants of application delays. We present both hazard and probit models of delays. Section 5 provides robustness checks to our main results. Section 6 concludes by summarizing our findings and discussing policy implications.

\footnotetext{
${ }^{4}$ Zhou (2012a) describes the probability of cartel dissolution and its determinants in 126 discovered cartels from the EC for the period December 1985 to December 2011.
} 


\section{BACKGROUND}

\subsection{Institutional features}

Understanding the motivation for our analysis requires a brief overview of how fine reductions are determined in a leniency program. In 1996, the EC introduced a leniency program, with the intent of detecting existing cartels and deterring new cartels. It provided discretionary fine reductions to first-in applicants, provided that an investigation into the applicant's cartel is not already underway. It precluded ringleaders - instigators or firms that had played a key role in a cartel - from applying for complete amnesty (i.e., 100 percent fine reduction). In 2002, the EC introduced a new leniency program. The program commits the EC to the lenient prosecution of early applicants. Since that date, complete amnesty has become guaranteed and automatic to first-in applicants, and the door of complete amnesty applications has been opened to ringleaders, provided that they did not coerce other firms to participate in the cartel. Both the 1996 and the 2002 leniency requires an eligible applicant to, upon reporting a cartel, promptly terminate its involvement in the cartel and fully cooperate with Commission investigation.

An important feature shared by the programs above is that cartel dissolution need not be concurrent with application: After a cartel collapses, a conspirator remains eligible to apply for complete amnesty until the cartel is unveiled in the event of a report by an accomplice or an independent Commission investigation. As we document below, throughout the period 1996 to 2012 there have been many cases where applicants obtained complete amnesty with applications postdating cartel dissolution by some months or even years.

A second important common feature of the programs is that they offer partial (i.e., less than 100 percent fine reduction) but discretionary amnesty to the second and subsequent applicants. Provided that the information reported is sufficiently novel, a late conspirator may apply for and obtain fine reductions throughout the investigation, from the date an initial inspection starts, to the time that a formal proceeding is initiated (i.e., the sending of the Statement of Objections), and up to the EC's final decision. As we report below, late applicants obtained generous fine reductions in many cases throughout the period 1996 to 2012.

The above two features are shared, in similar ways, by the contemporary leniency programs in Australia, Canada, China, France, Germany, Italy, Japan and South Korea. Although leniency programs in some jurisdictions (e.g., the United States, Israel and Brazil) preclude late applicants, fine reductions are available and have been provided through, for instance, plea-bargaining or settlement that are accomplished pursuant to a distinct procedure that falls 
outside of a leniency program (ICN 2008; O’Brien 2008; OCED 2012).

\subsection{Previous literature}

A large and growing game-theoretical literature, starting from Motta and Polo (2003) and reviewed in Rey (2003) and Spagnolo (2008), has studied the impact of leniency on cartel stability by examining conspirators' incentive to unveil a cartel. The primary force in the analyses has been that leniency may destabilize cartels because conspirators can simultaneously cheat on a cartel and disclose it for reduced penalty (e.g., Motta and Polo 2003, Spagnolo 2004, Chen and Harrington 2007, Harrington 2008). For instance, in Harrington (2008), when the detection probabilities (absent a conspirator's cooperation) is sufficiently high, cartels collapse immediately and all conspirators race for leniency. When the probability is sufficiently low, cartels are stable and conspirators never confess. Firms' incentive to report also may depend on market concentration (Ellis and Wilson 2003), the degree of firm heterogeneity (Motchenkova and van der Laan 2005), and the relationship between penalties and cartel profits (Motchenkova 2004).

This literature, however, suffers from a potential weakness that has thus far been ignored: the endogeneity in the timing of leniency application and, therefore, a conspirator's incentive to report a cartel. Our results - where delays in leniency applications are frequent and long - run contrary to the prediction of all previous theoretical models which is that conspirators either confess immediately after a cartel collapses or never confess.

Our empirical results most closely relate to those of Brenner (2005), Miller (2009) and Zhou (2012a). Brenner found limited evidence that the EC's 1996 leniency destabilized cartels. As discussed earlier, the EC did not promise full immunity to first-in applicants until 2002. Independently, Miller and Zhou test the efficacy of the new leniency programs in the United States and the European Union. They found that the new programs, with guaranteed and automatic full immunity for first-in applicants, enhanced the antitrust authorities' cartel-destabilization capabilities. Although these studies ignore the timing of leniency applications, their results are consistent with those presented here because they suggest that promised and automatic full immunity for first-in applicants may be an important element of successful leniency programs.

\section{Empirical Evidence on Leniency Application Delays}

\subsection{Data}

We sample data from EC cartel decisions issued over the period 1996 to 2012. Our analysis restricts to cartels that are eligible for leniency, i.e., cartels whose investigation ended after 
July 18, 1996 - the date of the old leniency introduction. ${ }^{5}$ The EC data currently include 110 cartels investigated by the EC between July 1996 and March 2012. A rich variety of casespecific information is recorded in the data, including the start and end dates of a cartel and those of Commission investigation, whether firms applied for leniency and if so, the date of the first application in the most of the cases. ${ }^{6}$ These are the key variables of interest in this paper. In order to isolate the effect of leniency revision from those of the other institutional changes, we restrict our sample to cartels whose first applications predate the publication of the White Paper on Damage Actions (April 2, 2008) - a major innovation in the EU's anti-cartel regime. ${ }^{7}$ One cartel is excluded due to this restriction. Furthermore, we exclude two cartels whose investigations ended after April 2, 2008 without a firm submitting an application. As discussed earlier, conspirators could apply throughout an investigation. Therefore, the White Paper might have affected application decisions in these cartels. Finally, we exclude 11 cartels because the dates of application is unknowable from publicly available data and it is impossible to make inferences in these cases. We refer to the 96 remaining cartels as our full sample. In 78 cartels of the full sample, firms applied for leniency. The 78 cartels are referred to as our reports sample. The main variables and model parameters are defined in Table 1.

[Table 1 about here]

The EC data suffers from a lack of reliable information on producer concentration. The variable has been shown to be an important determinant of cartel stability (Selten 1973) and conspirators' incentive to report (Ellis and Wilson 2003). Omission of this variable could well bias some of the estimated effects of leniency and those of other predictors in our empirical analysis. In many published decisions, market shares of cartel participants are omitted for confidentiality. Furthermore, apart from the US and Germany, data on concentration ratios and other summary measures of market structure are largely unavailable in official publications (Lyons et al. 2001, McCloughan and Abounoori 2003). Collecting data and constructing our own concentration ratios for each cartelized market are an enormous, if not impossible, task

\footnotetext{
${ }^{5}$ All EC cartel investigations that started before July 18, 1996 ended prior to February 19, 2002.

${ }^{6}$ Unless otherwise specified, all euro values throughout the paper are adjusted to $2010 €$ using standard measure of general price trends published by the OECD on the Producer Price Indices for prices, labor costs and interest rates of domestic manufacturing.

${ }^{7}$ The White Paper "suggests specific policy options and measures that would help giving all victims of EU antitrust infringements access to effective redress mechanisms so that they can be fully compensated for the harm they suffered". See http://ec.europa.eu/competition/antitrust/actionsdamages/index.html for details.
} 
and are beyond the scope of the present analysis. But to remedy at least in part the potential model misspecification bias, we include the total number of participating cartelists during a cartel's entire course to control for, among other things, difference in producer concentration across the cartelized markets. Given that the sampled cartels usually capture the majority, if not all, of all the market shares, the number of cartel members may serve as a (imperfect but reasonable) proxy for the number of market competitors. Moreover, EU-wide and worldwide markets are likely to have more competitors than national markets; Some industry types (e.g., mining) are likely to feature higher concentration than others (e.g., wholesale and retail trade) for reasons such as existence of entry and exit barriers (Mann 1966; Martin 1979). Therefore, we include the scope of the geographic markets (as determined by the EC in its decision) and the type of industries as additional controls for concentration.

Leniency application delays Firms may join and leave a cartel at different dates; Collusive agreements sometimes start in one region then spread over many regions (Levenstein and Suslow 2011). Most of our analysis uses the ending date of the last agreement to mark a cartel's downfall and to determine the duration of application delays. In robustness checks, we obtain similar results using alternative definitions of ending dates: the date that the first applicant leaves the cartel and the date of the first permanent exit by a conspirator.

Table 2 summarizes the principal statistics of application delay durations by leniency regime. A spell in this context refers to a period of application delay, which begins at the later of the cartel's end date and the date of the leniency introduction. The first two columns of statistics in Panel $\mathrm{A}$ are for all delay spells, including those ended in an investigation closure and the expiration of the old leniency program; The next two columns are for spells that ended in a leniency application; The final column is for spells with positive delay durations.

[Table 2 about here]

The results are quite stunning in terms of the prevalence of application delays, as over three-quarters of the applications by first-in applicants postdated cartel dissolution (Row 3, Column 4, Panel A). The prevalence of delays is particularly great for spells that ended before the new leniency, as over 40 percent of the applications are delayed for over a year. ${ }^{8}$

The mean value of DELAY, which includes spells that ended in an investigation or the leniency revision but not necessarily a leniency application, ranges from a low of nine months for the new leniency regime to a high value of 20 months for the old leniency.

\footnotetext{
${ }^{8}$ The figure is not reported in the table.
} 
These rather impressive statistics regarding the length of application delays may understate the importance of these concerns in the cases in which they arise. The statistics in the final column of Panel A, Table 2 describe the length of application delays excluding cartels where applications predated dissolution. The mean values of $D E L A Y$ s now exceed 12 months under both leniency regimes.

Panel B of Table 2 reports the median values that correspond to the entries in panel A. Because of the skewed distributions of the DELAY durations, the median values are below the means in most of the instances.

Moreover, we create a series of six-month periods to track application delays. The periods alternately begin on July 18 and February 19, so that they fit the introduction of the leniency programs on July 18, 1996 and February 19, 2002, respectively. We have observations for 17 periods in the data and we calculate the average DELAY in each period. Panel A of Figure 1 plots the mean duration of applications delays per period; Panel B plots the medians.

[Figure 1 about here]

Long application delays are prevalent under the old leniency regime: The mean values of $D E L A Y$ exceed 10 months in six out of eight periods prior to the leniency revision. After the new leniency introduction, long delays become occasional and applications become somewhat faster as in five out of nine periods the mean values of DELAY fall below five months.

Antitrust policies. A second set of variables captures aspects of the institutional environment where firms apply for leniency. $L E N I E N C Y$ is a dummy variable. It equals one if a spell ends after February 19, 2002; it equals zero if a spell ends before the date. MANPOWER is the annual number of EC DG Competition's staffs. The variable is included as a proxy for changes in the EC's investigatory intensity from year to year under the assumption that the probability that a cartel is investigated and detected increases in the EC's investigative resources, ceteris paribus.

$M A R G I N$ is the average difference in fine reductions between the first and second applicants during the pervious year. This variable controls for changes in the marginal incentive that the penalty regime provides firms with to come out ahead in denouncing a cartel. Because MARGIN is not defined for spells that ended before July 18, 1997 or if there was no application in the previous year, we only have 94 observations for this variable.

The EC's Fining Guidelines provide that the "basic amount of fines" - the level of fines 
in absence of offsetting leniency reductions - increases with the duration of an infringement. ${ }^{9}$ Our second penalty variable, DURATION, is a cartel's life span (in months) that is proven by documented evidence. ${ }^{10}$ The variable serves as a proxy for the scale of penalty that a conspirator would pay if he does not confess.

Macroeconomic Fluctuations and Market Structure. The remaining two sets of variables have been similarly defined and used in earlier empirical studies of leniency's efficacy in destabilizing and deterring cartels (Marquez 1994; Dick 1996; Suslow 2005; Zimmerman and Connor 2005). They reflect the possible variations in the market and macroeconomic environments where leniency applications take place. Some of these variables control for, at least in part, the potential heterogeneity in dissolution probabilities across the cartels.

It is perhaps by now mother's milk to industrial economists that in a repeated-game collusion is easier to sustain as players become more patient. The average annual interest rate with 3month maturity - INTEREST - is the short-term market rate of interest generally available to borrowers. It is used as a presumptive measure of fluctuations in firms' discount factor.

[Table 3 about there]

Received industrial organization theory also suggests that business cycle timing may affect cartels' stability (e.g., Green and Porter 1984; Rotemberg and Saloner 1986; Haltiwanger and Harrington 1991). I test for the effects of observable business cycle fluctuations with two variables: [1] the real GDP growth rate $(\triangle G D P)$; and [2] a dummy variable - PEAK-TROUGHindicating whether a cartel ends in a period of peak-to-trough.

There are a number of ways that the size of cartel membership - FIRMS - could affect or be associated with cartel stability. Besides reflecting (inversely) concentration, it may also influence, among other things, the costs of monitoring and coordinating a cartel (e.g., Stigler (1964), Dick (1996)). It is worth to note that the existence of some cartels with a large number of firms is not as paradoxical as it may appear: many cartels with a large membership are monitored and coordinated by a trade association. ${ }^{11}$

\footnotetext{
${ }^{9}$ The basic amount also does not take into account varies aggravating and mitigating circumstances such as, among others, whether a firm was playing a leader's role and whether the firm had a limited extent of involvement.

${ }^{10}$ We obtain similar results using suspected cartel durations.

${ }^{11}$ Levenstein and Suslow (2011) make a similar remark on the large number of cartel participation. Brenner (2009) makes a similar remark on the role of trade association in monitoring and coordinating cartels.
} 
Finally, I include two categorical variables, INDUSTRY TYPE and MARKET-SCOPE, to control for the effects of omitted cartel-specific characteristics (e.g., price transparency, market concentration, industry-specific cyclicality, etc.) that may be correlated with both dissolution likelihood and the included variables of interest. Table 3, Panel B of the online Appendix reports the distribution of industry types and market scope.

\subsection{Hazard model estimates of determinants of delay}

The leniency application decision is analyzed most naturally in a hazard model framework. A spell in this context refers to a period of application delay, which begins at the later of the cartel's end date and the date of the leniency introduction. In what follows, we discuss two alternative empirical specifications and investigate the robustness of the results. The second specification is a generalization of the first.

- Cox's (1972) semiparametric proportional hazard model is the most popular approach towards characterizing the hazard function $h(t ; \cdot)$. The model is flexible enough to account for potential inappropriate distribution assumptions that may be involved in parametric methods. ${ }^{12}$ The hazard function for spell $i$ is

$$
h_{i}\left(t ; \mathbf{x}_{i}\right)=h_{0}(t) \times \exp \left(\mathbf{x}_{i}^{\prime} \beta\right)
$$

where $t$ is the difference (in months) between the date of the first application and the later of the date of cartel dissolution and the date of the leniency introduction. $\mathbf{x}_{i}$ is a vector of observed explanatory variables. The parameter vector $\beta$ is the vector of coefficients, measuring the influence of observed characteristics. The term $\exp \left(\mathbf{x}_{i}^{\prime} \beta\right)$ shifts the baseline hazard function $h_{0}(t)$, and a positive coefficient indicates that the observed characteristics increase the application hazard and reduce the delay. The model is semiparametric in that the baseline hazard $h_{0}(t)$ is a nonparametric function of time, with the influence of other observable characteristics specified assuming a particular functional form. Furthermore, the model is a proportional hazard one since the ratio of the hazard function for any group with certain observed characteristics to that of the baseline hazard equals a constant, dependent only on the observed characteristics; i.e, $h(t) / h_{0}(t)$, the relative hazard function, is not time varying.

Suppose that there are $n$ observations and $k$ distinct leniency application delay times. Further suppose that we can rank the application times such that $t_{1}<t_{2}<\ldots<t_{k}$ where $t_{j}$

\footnotetext{
${ }^{12}$ The advantages of using Cox (1972) model to analyze time to event data have been widely recognized. See, e.g., Kalbfleisch and Prentice (1980), Meyer (1990), and Perperoglou (2005).
} 
denotes the application time for the $j$ th spell. Furthermore, let $R_{j}$ denote the set of spells have not applied for leniency until time $t_{j}$. Then the probability that the $\ell$ th application will take place at time $t_{j}$ given that some conspirators in set $R_{j}$ will apply for leniency at time $t_{j}$ is

$$
\frac{h_{\ell}\left(t_{j} ; \mathbf{x}_{\ell}\right)}{\sum_{\tau \in R_{j}} h_{\tau}\left(t_{j} ; \mathbf{x}_{\tau}\right)}=\frac{\exp \left(\mathbf{x}_{\ell}^{\prime} \beta\right)}{\sum_{\tau \in R_{j}} \exp \left(\mathbf{x}_{\tau}^{\prime} \beta\right)}
$$

Taking the product of the conditional probabilities in (1) yields the partial likelihood function

$$
\mathcal{L}=\prod_{j}\left[\frac{\exp \left(\mathbf{x}_{j}^{\prime} \beta\right)}{\sum_{\tau \in R_{j}} \exp \left(\mathbf{x}_{\tau}^{\prime} \beta\right)}\right]
$$

with corresponding log-likelihood function

$$
\ln \mathcal{L}=\sum_{j}\left[\mathbf{x}_{j}^{\prime} \beta-\ln \sum_{\tau \in R_{j}} \exp \left(\mathbf{x}_{\tau}^{\prime} \beta\right)\right]
$$

- Cox's competing risks model. An investigation can end in two ways: (1) with amnesty applications prior to or during its course; or (2) without a conspirator reporting. In the latter case, we can only infer that spell durations would have continued beyond the date that the investigation ended, but was censored at the date. Moreover, in nine cartels that collapsed prior to the leniency revision (February 19, 2002), one of the two situations arose: (1) applications by first-in applicants postdated the revision (five cartels); or (2) the investigation ended after the revision without a firm reporting (four cartels). For these cartels, delay spells under the 1996 Leniency Notice are censored at February 19, 2002: We can only infer that DELAY would have continued beyond the date if the old program were not revised. Estimation of the application hazard function from observed DELAY times must also consider the censoring of application delays for cartels whose spells ended in an investigation closure or the leniency revision.

A popular choice towards the analysis of competition risks is using a stratified Cox model from augmented data (Lunn and McNeil 1995). Let $\phi$ denote a spell's failure type where $\phi=0$ indicates those spells that ended in a leniency application; $\phi=1$ indicates those spells ended in an investigation closure; $\phi=2$ indicates the spells ended in the leniency revision. The joint distribution of failure times and cause of failure is considered and the hazard function of a particular cause in the presence of all other causes is estimated. In the absence of ties (i.e., multiple cartel groups apply for leniency at the same $t_{j}$ ) the full partial log-likelihood is given by

$$
\ln \mathcal{L}=\sum_{j, \phi_{j}=0} \mathbf{x}_{j}^{\prime} \beta+\sum_{\phi_{j}=1}^{2} \sum_{j}\left(\beta_{\phi_{j}}+\mathbf{x}_{j}^{\prime} \beta\right)-\sum_{j} \ln \left[\sum_{\tau \in R_{j}}\left(\exp \left(\mathbf{x}_{\tau}^{\prime} \beta\right)+\sum_{\phi_{j}=1}^{2} \exp \left(\beta_{\phi_{j}}+\mathbf{x}_{\tau}^{\prime} \beta\right)\right)\right],
$$


where $\beta_{\phi_{j}}$ (with $\left.\phi_{j}=1,2\right)$ is a constant so that the baseline hazard functions for the different types of risk differ by a constant ratio.

Running standard Cox regression on the augmented data set gives the appropriate estimates of the regression coefficients, provided the model fit is good. The partial likelihood which results from the method is precisely the partial likelihood suggested by Kalbfleisch and Prentice (1980) for competing risks.

- Hazard model estimates. Table 3 reports the competing risks Cox regression estimates of the coefficients. Unless otherwise stated, the coefficient of interest throughout the paper is that of the $L E N I E N C Y$, the effect of the leniency revision on application delays.

Column (1) shows that the leniency revision immediately results in a hazard profile with shorter application delays. The estimated LENIENCY coefficient is positive and statistically significant, and corresponds to a 102 percent $(\exp \{0.705\}-1 \approx 102 \%)$ increase in the application hazard from the pre-revision level. Figure 3 depicts this relationship diagrammatically. Columns (2) and (3) show that the impact of the new leniency is quite similar to that in (1) with controls for changes in macroeconomic conditions (column (2)) and the effects of market structures (column (3)). In Column (4), I add the number of the EC DG Competition's staffsMANPOWER - as a crude measure of year-to-year changes in the likelihood that a cartel is investigated and caught. This does not change the significance of my results but considerably increases the magnitude of $L E N I E N C Y$ 's impact: The coefficient now corresponds to nearly a triple increase $(\exp \{1.373\}-1 \approx 2.95)$ in the application hazard. This is consistent with the view that the firms' incentive to report critically depends on the probability of independent antitrust investigation and apprehension (e.g., Harrington 2008; Harrington and Chang 2009). Column (5) includes all the exogenous covariates and LENIENCY. The impact of the new leniency remains large and statistically significant. In column (6), I add the duration of infringement and a dummy to indicate whether the EC's surprise inspection predates the application. Including the variables may give rise to endogeneity concerns. The main point here is that the strong, negative and statistically insignificant impact of the new leniency on application delays is unaffected by the inclusion of these variables as additional controls in the specification.

[Insert Table 4 Here]

[Insert Fig. 3 Here] 
- Probit model estimates. Our hazard models consider the marginal impact of antitrust policies and economic conditions on delay in general. But of particular concern is the impact of changes in these factors on reasonably long delays, since these are the cases that are of most relevance for both policy-making and empirical work on cartel stability and leniency application behavior. We therefore, in Table 4, reestimate our models as probit models of the decision to delay application at least 12 months. As mentioned earlier, the mean of this dependent variable is $41.9 \%$.

Table 4 reports the probit coefficients and standard errors. We expect all coefficients to switch signs, as a positive coefficient in the probit indicates a higher likelihood of delay. This is precisely what we find. The $L E N I E N C Y$ coefficients remain large and significant. In particular, the new leniency introduction leads to a 116 percent decrease in $L O N G-D E L A Y \mathrm{~s}(\exp \{0.772\}-$ $1 \approx 116 \%$ ). Likewise, we continue to see a positive correlation between MANPOWER and application delays (columns (10), (11) and (12)). But as in the case of the hazard models (columns (5) and (6)), the coefficients of the investigatory resource variable remain insignificant.

Thus, the probit estimates confirm the pattern of our main findings from the hazard models. For LENIENCY, the effects are similar in magnitude to those in the hazard models, suggesting that the new leniency may play an important role in reducing long delays as well as in reducing short delays. Indeed, if we reestimate these probit models with a dummy for any delay, as opposed to a dummy for long delays, we obtain similar significant results on LENIENCY.

\section{Additional Robustness Checks}

Our empirical strategy is implemented using a before-and-after comparison across groups where the date of leniency revision - February 19, 2002 - is used as an exogenous shock to identify the impact of the revision. Our concern here is that if alternative shocks - i.e., placebo policiesyield a better fit to the data, then the link between leniency introductions and the changes in observed cartel durations over time might not be causal. ${ }^{13}$ To investigate, we borrow the method of Miller (2009) and re-run the regression in column (5) of Table 3 but use alternative time breakpoints in the data and compare the maximized log-likelihoods across the different specifications.

Each points on the graphs of Figure 4 corresponds to the maximized log-likelihood of one Cox regression. The point located at zero on the horizontal axes marks the maximized loglikelihood when the shocks are imposed at the leniency revisions. The points to the left (resp.

\footnotetext{
${ }^{13}$ In a similar way, Miller (2009) motivates his robustness tests of placebo policy interventions.
} 
right) of zero represent the log-likelihoods when the shocks are imposed before (resp. after) February 19, 2002. Panel A uses six-month periods. The maximized log-likelihood generated by leniency $(-282.369)$ is greater than those generated by all but two placebo policy shocks. The offending placebo policy that predates the leniency revision corresponds not to a fall but a sharp increase in DELAY of one spell that ended in the fifth period before February 19, 2002. The offending placebo policy that postdates the revision corresponds to a dramatic increase in $D E L A Y$ of one spell that ended in the fifth period following the revision. Panels $\mathrm{B}$ and $\mathrm{C}$ use three-month and twelve-month periods, respectively. The results are largely similar to that in the six-month case. In the twelve-month case, the regression fit is globally maximal when the shock is imposed at February 19, 2002.

[Insert Fig. 4 Here]

\section{Conclusion}

The social costs of cartel have motivated an extensive literature investigating the efficacy and design of anti-cartel policies. While there is a large literature on leniency application decisions, we are not aware of any previous analysis of delays in applications.

We find a high prevalence of delay in leniency application empirically that is so far overlooked by the theoretical models. Our hazard and probit modeling suggest that delays are systematically correlated with the severity of punishment and business cycles. In particular, we find support for the hypothesis that delays tend to be shorter after the new leniency introduction. But we did not find support for the hypothesis that the introduction of the EC's new leniency shortens delay. Our research has implications for the large literature on collusion, in particular the impacts of leniency on cartel stability and market efficiency. 


\begin{tabular}{|c|c|}
\hline & Definition \\
\hline Cartel & $\begin{array}{l}\text { An agreement or a series of agreements between competing firms or associations of firms } \\
\text { that constitutes a single infringement, according to the EC, of Art. } 101 \text { (formerly } \\
\text { Art. } 81 \text { and Art. } 85 \text { ) of the EC treaty. }\end{array}$ \\
\hline END DATE & Ending date of the last agreement(s) between any two (or more) cartel participants. \\
\hline END DATE-2 & The date that the first applicant leaves the cartel. \\
\hline END DATE-3 & The date of the first permanent departure from the cartel by a participant. \\
\hline \multicolumn{2}{|l|}{ DEPENDENT VARIABLES } \\
\hline \multirow{15}{*}{$\begin{array}{l}D E L A Y \text { (resp. DE- } \\
L A Y-2, D E L A Y-3)\end{array}$} & 0 if the first application predates END DATE (resp. END DATE-2, END DATE-3); \\
\hline & If the first application postdates END DATE (resp. END DATE-2, END DATE-3), \\
\hline & the difference (in months) between the date of the first application and the later of \\
\hline & END DATE (resp. END DATE-2, END DATE-3) and the initiation date of the \\
\hline & leniency (under the terms of which the application is made); \\
\hline & If a cartel collapsed before February 19, 2002 and one of the two following situations \\
\hline & arises: (1) the first application postdated February 19,2002 ; or (2) the investigations \\
\hline & ended after February 19, 2002 with conspirators applying for amnesty, we distinguish \\
\hline & $D E L A Y$ (resp. DELAY-2, DELAY-3) under the new policy (as defined above) \\
\hline & from (censored) $D E L A Y$ (resp. $D E L A Y-2, D E L A Y-3)$ under the old leniency. We \\
\hline & measure the latter as the months elapsed from END DATE (resp. END DATE-2, \\
\hline & END DATE-3) to February 18, 2002. \\
\hline & If firms did not apply for amnesty, the difference (in months) between the date that \\
\hline & the EC issues its prohibition decision and the later of the cartel's END DATE (resp. \\
\hline & $E N D D A T E-2, E N D D A T E-3)$ and the date of the leniency introduction. \\
\hline$L O N G-D E L A Y$ & 1 if $D E L A Y$ is longer than one year; 0 otherwise. \\
\hline
\end{tabular}

INDEPENDENT VARIABLES

Antitrust Policies

LENIENCY Dummy variable $=1$ if a spell ends after February 19, $2002=0$ prior to the date.

MANPOWER The annual number of EC DG Competition's staffs.

DURATION A cartel's duration (months) that is proven by documented evidence.

INSPECION Dummy variable $=1$ if the Commission's surprise inspection predates the first application $=0$ otherwise.

$M A R G I N$

The difference in percentage fine reductions between the first and second applicants.

\section{Macroeconomic Fluctuations, Firm Impatience and Industry Concentration}

PEAK-TROUGH $\quad 1$ if a spell ends in a peak-to-trough period of a business cycle; 0 otherwise. If the relevant geographic market consisted of multiple economic areas in multiple count- 


\section{Definition}

ries, it is the weighted average of the indicators. The weight applied is the annual national GDP.

$\triangle G D P$

Semi-annual growth rate of the real domestic product of the relevant geographic market (according to the EC). If the relevant geographic market consisted of multiple economic areas in multiple countries, it is the weighted average of the rates. The weight applied is the semi-annual national GDP.

INTEREST Annual average (real) short-term interest rates, 3-month maturity. If the relevant geographic market consisted of multiple economic areas in multiple countries, it is the weighted average of the rates. The weight applied is the annual national GDP.

INDUSTRY TYPE Categorical variable indicating the type of industry where a cartel operates. The industry types are wholesale and retail trade; food, feed, tobacco and other agricultural products; chemicals; transport; primary material; machinery, equipment and metal products; and other products and services.

MARKET-SCOPE Categorical variable indicating the geographic scope of cartelized market. The scopes are national, multinational (but less than EU-wide), EEA-wide or EU-wide, and worldwide. 
Panel A: Mean Application Delays

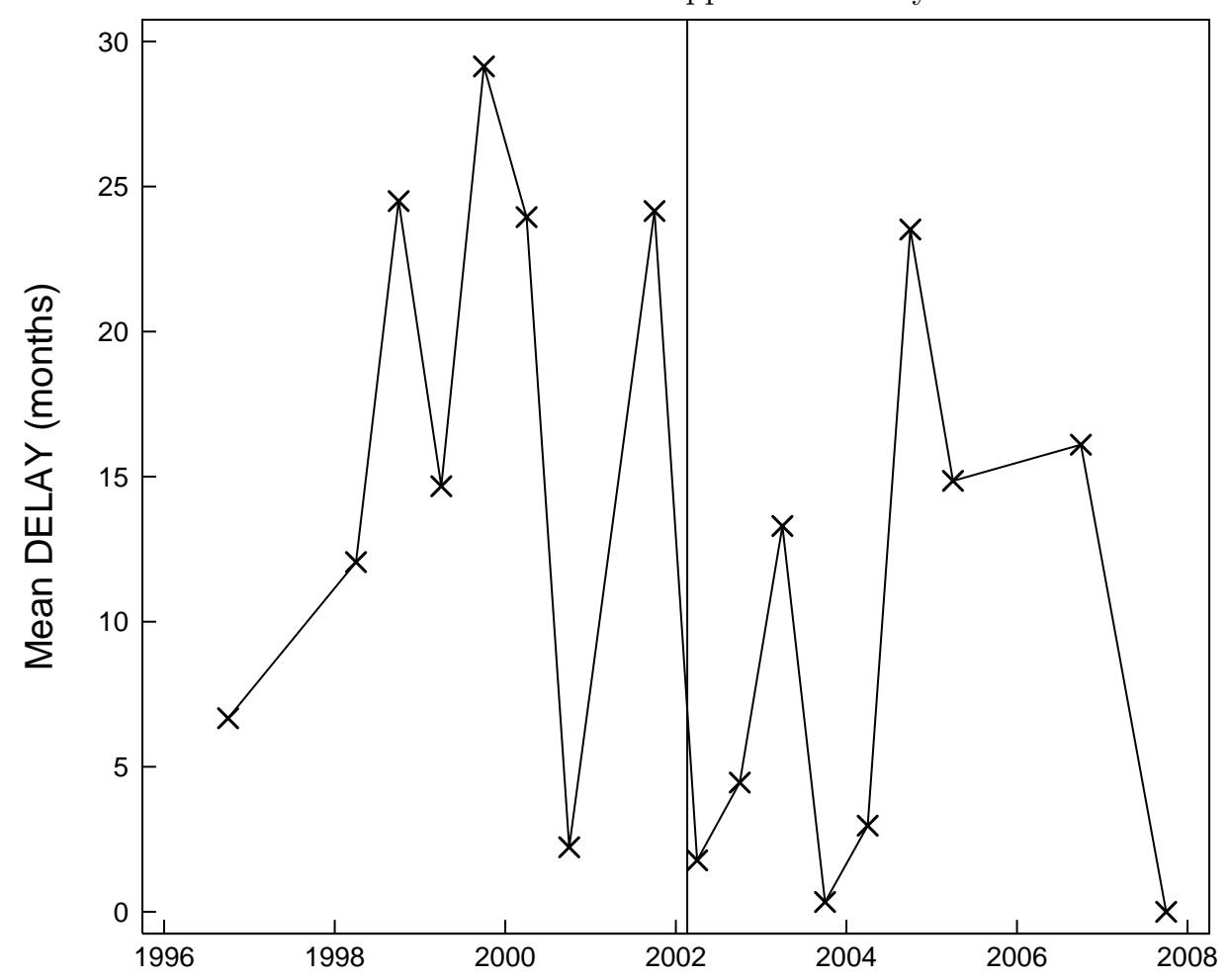

Panel B: Median Application Delays

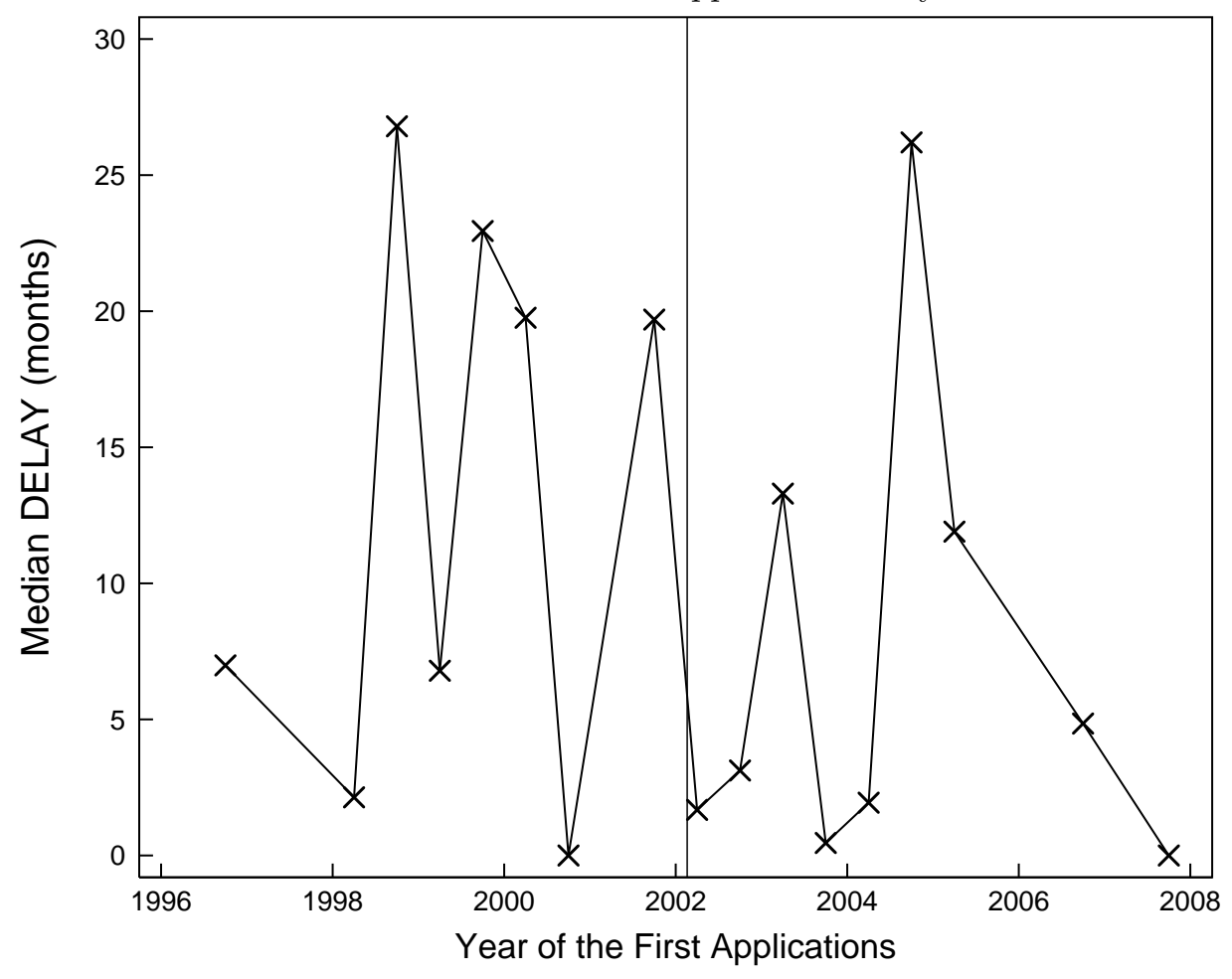

Figure 1. Average Application Delay Duration per SiX-Month Period

Notes: The sample of spells runs from July 1996 to October 2007. The vertical bars mark the introduction of the new leniency program on February 19, 2002. Panel A plots the semi-annual means of leniency application delays starting from the later of the ending date of a cartel's last agreement and the date of the leniency introduction; Panel B plots the medians. The source for these values is authors' calculations based on 96 EC cartel decisions issued over the period 1996-2012. 
Panel A: Average Fine Reductions

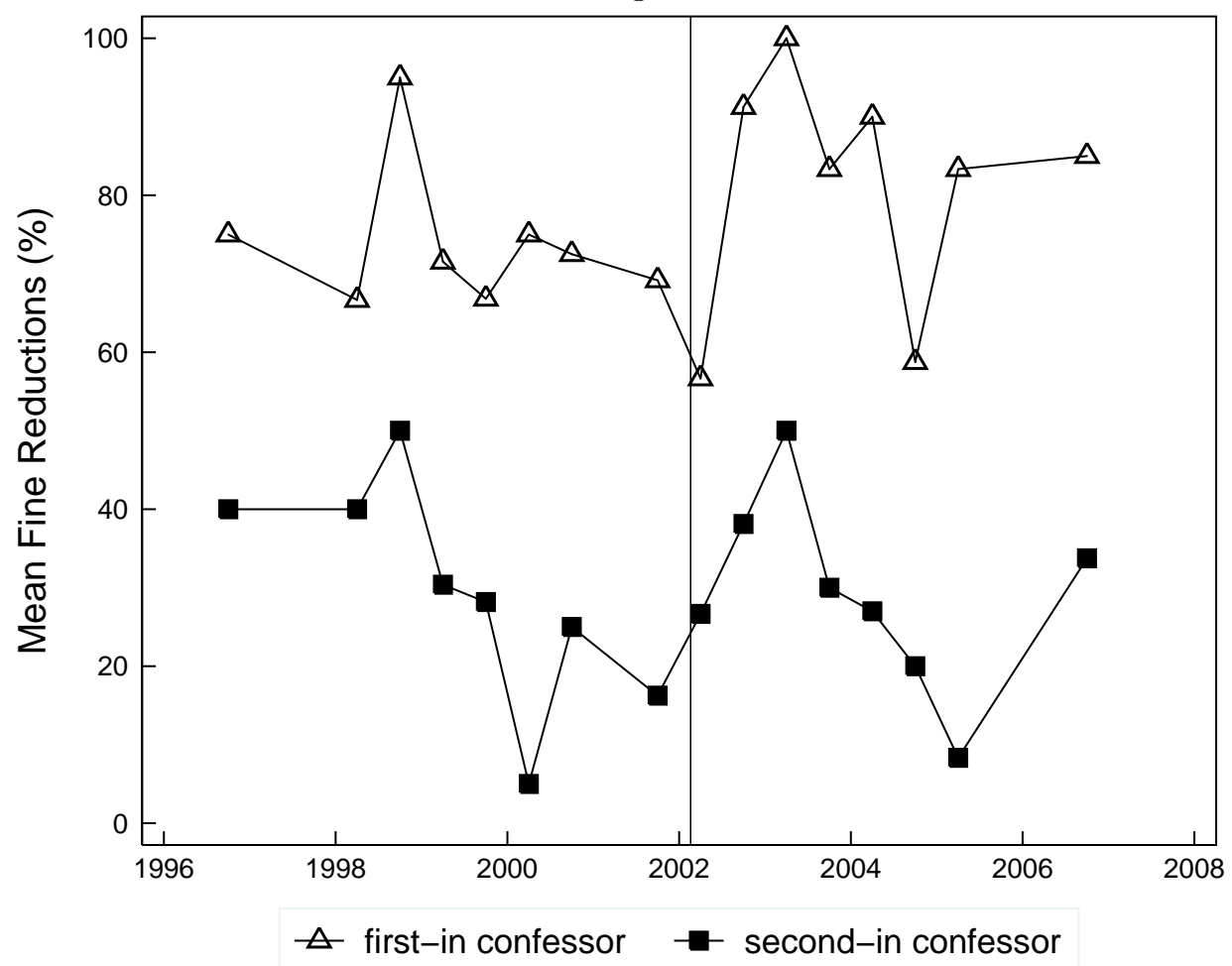

Panel B: Average Marginal Fine Reductions

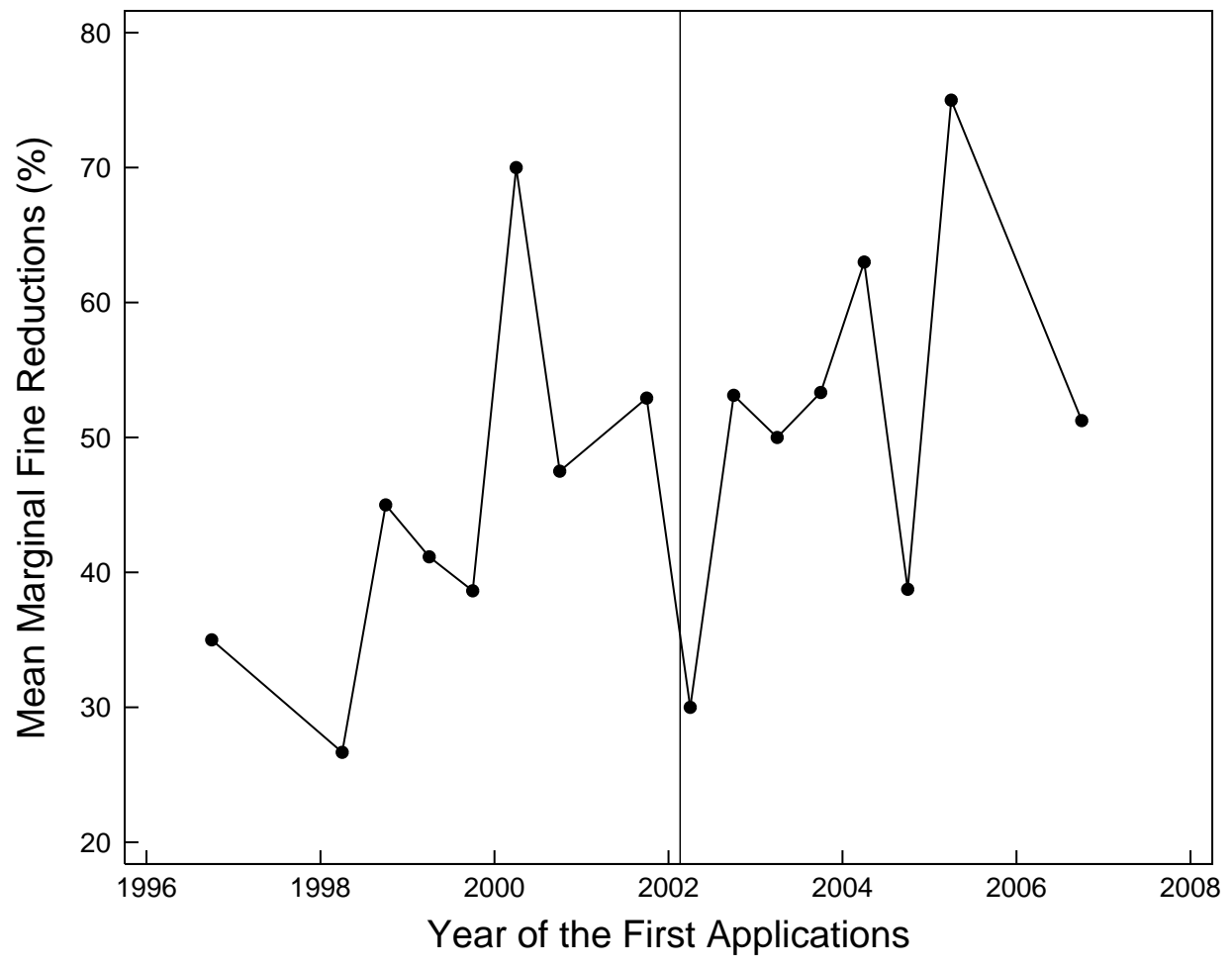

Figure 2. Average Fine Reductions and Average Marginal Fine Reductions Per SiX-Month Period

Notes: The sample of leniency applications runs from July 1996 to January 2007. Panel A plots the semi-annual means of fine reductions for the first and second applicants, respectively. Panel B plots the semi-annual means of the differences in fine reductions between the first and second applicants (i.e., the marginal fine reductions). The vertical bars mark the introduction of the new leniency program on February 19, 2002. The source for these values is authors' calculations based on 78 cartels with leniency applications that were prosecuted by the EC over the period 1996-2012. 


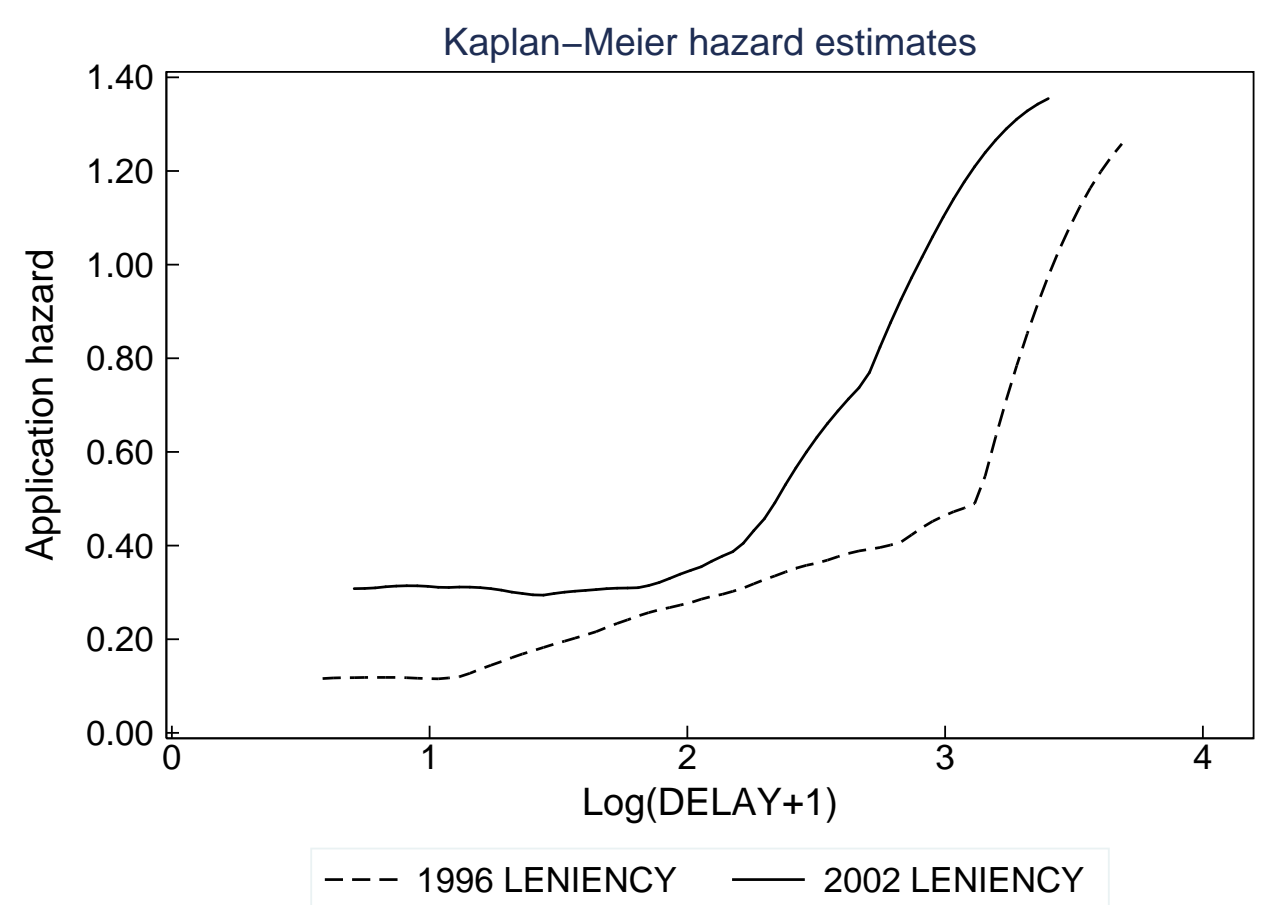

Figure 3. The Impact of The EC's New Leniency

Notes: The solid line corresponds to delay spells under the EC's 2002 Leniency Notice. The dashed line corresponds to delay spells under the EC's 1996 Leniency Notice. The source for these values is authors' calculations based on 96 EC cartel decisions issued over the period 1996-2012. 


\section{Appendix}

Table 2. Distribution of The Duration of Leniency Application Delays [in months]

Panel A: Means (Standard Deviations) and Fractions of Spells with Positive DELAYs

\begin{tabular}{|c|c|c|c|c|c|}
\hline \multirow[b]{5}{*}{ Leniency Program } & \multicolumn{2}{|c|}{ Full Sample } & \multicolumn{2}{|c|}{ Reports Sample } & \multirow[t]{4}{*}{$\begin{array}{c}\text { Spells with } \\
\text { Positive DELAYs }\end{array}$} \\
\hline & & Fraction of & & Fraction of & \\
\hline & & Spells with & & Spells with & \\
\hline & & Positive & & Positive & \\
\hline & Mean (Std. Dev.) & $D E L A Y \mathrm{~s}$ & Mean (Std. Dev.) & $D E L A Y \mathrm{~s}$ & Mean (Std. Dev.) \\
\hline EC's 1996 Leniency & $20(21)$ & 0.81 & $17(20)$ & 0.80 & $22(20)$ \\
\hline EC's 2002 Leniency & $9(13)$ & 0.76 & $9(14)$ & 0.73 & $12(15)$ \\
\hline Both programs & $16(19)$ & 0.79 & $14(18)$ & 0.77 & $18(19)$ \\
\hline Observations & \multicolumn{2}{|l|}{105} & \multicolumn{2}{|l|}{78} & 83 \\
\hline \multicolumn{6}{|l|}{ Panel B: Medians } \\
\hline & & & & & Spells with \\
\hline Leniency Program & \multicolumn{2}{|c|}{ Full Sample } & \multicolumn{2}{|c|}{ Reports Sample } & Positive DELAYs \\
\hline EC's 1996 Leniency & \multicolumn{2}{|l|}{20} & \multicolumn{2}{|l|}{9} & 14 \\
\hline EC's 2002 Leniency & \multicolumn{2}{|l|}{4} & \multicolumn{2}{|l|}{3} & 5 \\
\hline Both programs & \multicolumn{2}{|l|}{7} & \multicolumn{2}{|l|}{6} & 10 \\
\hline Observations & \multicolumn{2}{|c|}{105} & \multicolumn{2}{|l|}{78} & 83 \\
\hline
\end{tabular}

SourCE.- Authors' calculations based on 96 cartel decisions by the European Commission and judgments of the Court of First Instance and the European Court of Justice for the period 1996-2012.

NoтE.- An "observation" corresponds to a spell which is a period of application delays starting from the later of the ending date of a cartel's last agreement and the date of the leniency introduction. 
Table 3. Descriptive Statistics:Antitrust Policies, Market and Macroeconomic Conditions

\begin{tabular}{|c|c|c|c|c|c|c|}
\hline & \multicolumn{2}{|c|}{$\begin{array}{c}\text { EC's } 1996 \\
\text { Leniency Program }\end{array}$} & \multicolumn{2}{|c|}{ EC's 2002} & \multicolumn{2}{|c|}{ Both Programs } \\
\hline & Mean & Std. Dev. & Mean & Std. Dev. & Mean & Std. Dev. \\
\hline \multicolumn{7}{|l|}{ Antitrust Policies } \\
\hline LENIENCY (1=yes) & 0.00 & 0.00 & 1.00 & 0.00 & 0.39 & 0.49 \\
\hline MANPOWER & 450.97 & 45.36 & 578.15 & 41.72 & 500.63 & 76.17 \\
\hline INSPECTION (1=yes) & 0.67 & 0.47 & 0.49 & 0.51 & 0.6 & 0.49 \\
\hline DURATION (month) & 82.98 & 67.76 & 106.47 & 99.57 & 92.15 & 82.02 \\
\hline \multicolumn{7}{|l|}{ MACROECONOMIC CONDITIONS } \\
\hline$\Delta G D P(\%)$ & 2.82 & 1.22 & 1.97 & 0.92 & 2.49 & 1.18 \\
\hline PEAK-TROUGH (1=yes) & 0.49 & 0.55 & 0.30 & 0.43 & 0.42 & 0.51 \\
\hline INTEREST (\%) & 3.73 & 1.35 & 2.60 & 0.72 & 3.29 & 1.27 \\
\hline \multicolumn{7}{|l|}{ MARKET Conditions } \\
\hline \multirow[t]{2}{*}{ FIRMS } & 6.38 & 4.99 & 278.49 & 1716.43 & 112.63 & 1072.81 \\
\hline & $\mathrm{N}$ & $\%$ & $\mathrm{~N}$ & $\%$ & $\mathrm{~N}$ & $\%$ \\
\hline \multicolumn{7}{|l|}{ MARKET CONDITIONS } \\
\hline \multicolumn{7}{|l|}{ INDUSTRY TYPE } \\
\hline Wholesale \& retail trade & 3 & 4.69 & 3 & 7.32 & 6 & 5.71 \\
\hline Food, feed, tobacco \& other agr. products & 6 & 9.38 & 2 & 4.88 & 8 & 7.62 \\
\hline Primary material & 4 & 6.25 & 8 & 19.51 & 12 & 11.43 \\
\hline Chemicals & 25 & 39.06 & 8 & 19.51 & 33 & 31.43 \\
\hline Machinery, equipment\& metal products & 11 & 17.19 & 11 & 26.83 & 22 & 20.95 \\
\hline Transport & 6 & 9.38 & 1 & 2.44 & 7 & 6.67 \\
\hline Other products \& services & 9 & 14.06 & 8 & 19.51 & 17 & 16.19 \\
\hline \multicolumn{7}{|l|}{$M A R K E T S C O P E$} \\
\hline National & 14 & 21.88 & 15 & 36.59 & 29 & 27.62 \\
\hline Multinational & 6 & 9.38 & 3 & 7.32 & 9 & 8.57 \\
\hline EU-wide or EEA-wide & 16 & 25.00 & 15 & 36.59 & 31 & 29.52 \\
\hline Worldwide & 28 & 43.75 & 8 & 19.51 & 36 & 34.29 \\
\hline Observations & & 64 & & 41 & & 05 \\
\hline
\end{tabular}

Source.- Authors' calculations based on the decisions on 96 cartels by the European Commission and judgments of the Court of First Instance and the European Court of Justice for the period 1996-2012.

Note.- All euro values are in $2005 €$. An "observation" corresponds to a spell which is a period of application delays starting from the later of the ending date of a cartel's last agreement and the date of the leniency introduction.

a.- For MARGIN, we have 49 observation for spells ended before February 19, 2002 and 34 observations for spells ended after February 19, 2002. 
Table 3. Cox Proportional Hazard Model Estimates of Leniency Application Delays

\begin{tabular}{|c|c|c|c|c|c|c|}
\hline & \multicolumn{6}{|c|}{$\log (D E L A Y+1)$} \\
\hline & (1) & $(2)$ & (3) & $(4)$ & $(5)$ & (6) \\
\hline \multicolumn{7}{|l|}{ Leniency program dummy } \\
\hline \multirow[t]{2}{*}{ LENIENCY } & $0.705^{* * *}$ & $0.971^{* * *}$ & $0.710^{* * *}$ & $1.373^{* * *}$ & $1.185^{* *}$ & $1.238^{* *}$ \\
\hline & $(0.219)$ & $(0.286)$ & $(0.268)$ & $(0.469)$ & $(0.538)$ & $(0.530)$ \\
\hline \multicolumn{7}{|l|}{ Control variables } \\
\hline \multirow[t]{2}{*}{$\log (\Delta G D P)$} & & 0.168 & & & 0.098 & 0.538 \\
\hline & & $(0.304)$ & & & $(0.328)$ & $(0.448)$ \\
\hline \multirow[t]{2}{*}{$\log (P E A K-T R O U G H+1)$} & & -0.104 & & & 0.144 & 0.498 \\
\hline & & $(0.481)$ & & & $(0.551)$ & $(0.641)$ \\
\hline \multirow[t]{2}{*}{$\log (I N T E R E S T)$} & & 0.721 & & & 0.912 & 0.520 \\
\hline & & $(0.460)$ & & & $(0.657)$ & $(0.646)$ \\
\hline \multirow[t]{2}{*}{$\log (F I R M S)$} & & & 0.047 & & 0.032 & -0.136 \\
\hline & & & $(0.136)$ & & $(0.139)$ & $(0.149)$ \\
\hline Industry fixed effects & & & yes & & yes & no \\
\hline Market scope & & & no & & no & no \\
\hline \multirow[t]{2}{*}{$\log (M A N P O W E R)$} & & & & $-2.431^{*}$ & -0.183 & -0.668 \\
\hline & & & & $(1.438)$ & $(1.568)$ & $(1.569)$ \\
\hline \multirow[t]{2}{*}{$\log (D U R A T I O N)$} & & & & & & $0.587^{* * *}$ \\
\hline & & & & & & $(0.155)$ \\
\hline \multirow[t]{2}{*}{ INSPECTION } & & & & & & $-1.378^{* * *}$ \\
\hline & & & & & & $(0.351)$ \\
\hline Number of Observations & 105 & 105 & 105 & 105 & 105 & 105 \\
\hline Number of failures & 78 & 78 & 78 & 78 & 78 & 78 \\
\hline Time at risk & 215.578 & 215.578 & 215.578 & 215.578 & 215.578 & 215.578 \\
\hline Log-pseudo likelihood & -292.564 & -290.819 & -284.112 & -291.084 & -282.369 & -266.703 \\
\hline
\end{tabular}

Note.- The table reports competing risks Cox-proportional hazard model estimates. Standard errors are robust to heteroskedasticity and are shown in parentheses. Omitted LENIENCY category is "the EC's 1996 Leniency". Omitted industry category is "wholesale and retail trade". Omitted market scope category is "national market". The source for these values is authors' calculations based on the decisions on 96 cartels by the European Commission and judgments of the Court of First Instance and the European Court of Justice for the period 1996-2012.

*** Significant at the 1 percent level.

** Significant at the 5 percent level.

* Significant at the 10 percent level. 
Table 4. Probit Model Estimates of Long Leniency Application Delays

\begin{tabular}{|c|c|c|c|c|c|c|}
\hline & \multicolumn{6}{|c|}{$L O N G-D E L A Y$} \\
\hline & $(7)$ & $(8)$ & (9) & (10) & $(11)$ & $(12)$ \\
\hline \multicolumn{7}{|l|}{ Leniency program dummy } \\
\hline LENIENCY & $\begin{array}{c}-0.772^{* * *} \\
(0.266)\end{array}$ & $\begin{array}{c}-1.158^{* * *} \\
(0.333)\end{array}$ & $\begin{array}{c}-0.741^{* * *} \\
(0.289)\end{array}$ & $\begin{array}{c}-1.351^{* * *} \\
(0.436)\end{array}$ & $\begin{array}{c}-1.810^{* * *} \\
(0.504)\end{array}$ & $\begin{array}{c}-1.934^{* * *} \\
(0.542)\end{array}$ \\
\hline \multicolumn{7}{|l|}{ Control variables } \\
\hline $\log (\Delta G D P)$ & & $\begin{array}{l}-0.120 \\
(0.246)\end{array}$ & & & $\begin{array}{l}-0.210 \\
(0.317)\end{array}$ & $\begin{array}{l}-0.433 \\
(0.321)\end{array}$ \\
\hline $\log (P E A K-T R O U G H+1)$ & & $\begin{array}{c}0.059 \\
(0.531)\end{array}$ & & & $\begin{array}{l}-0.023 \\
(0.680)\end{array}$ & $\begin{array}{l}-0.170 \\
(0.684)\end{array}$ \\
\hline $\log (I N T E R E S T)$ & & $\begin{array}{c}-0.923^{*} \\
(0.472)\end{array}$ & & & $\begin{array}{c}-1.640^{* * *} \\
(0.585)\end{array}$ & $\begin{array}{c}-1.539^{* *} \\
(0.609)\end{array}$ \\
\hline $\log (F I R M S)$ & & & $\begin{array}{l}-0.183 \\
(0.164)\end{array}$ & & $\begin{array}{l}-0.235 \\
(0.201)\end{array}$ & $\begin{array}{l}-0.018 \\
(0.146)\end{array}$ \\
\hline Industry fixed effects & & & no & & no & no \\
\hline Market scope & & & no & & yes & yes \\
\hline $\log (M A N P O W E R)$ & & & & $\begin{array}{c}2.243 \\
(1.398)\end{array}$ & $\begin{array}{c}0.927 \\
(1.942)\end{array}$ & $\begin{array}{c}1.431 \\
(1.954)\end{array}$ \\
\hline $\log (D U R A T I O N)$ & & & & & & $\begin{array}{c}-0.426^{* * *} \\
(0.160)\end{array}$ \\
\hline INSPECTION & & & & & & $\begin{array}{c}1.021^{* * *} \\
(0.354)\end{array}$ \\
\hline Constant & $\begin{array}{c}0.078 \\
(0.158)\end{array}$ & $\begin{array}{c}1.344^{* *} \\
(0.585)\end{array}$ & $\begin{array}{c}0.688 \\
(0.638)\end{array}$ & $\begin{array}{c}-13.618 \\
(8.538)\end{array}$ & $\begin{array}{c}-2.758 \\
(12.269)\end{array}$ & $\begin{array}{c}-6.539 \\
(12.415)\end{array}$ \\
\hline Number of Observations & 105 & 105 & 105 & 105 & 105 & 105 \\
\hline Pseudo- $R^{2}$ & 0.061 & 0.091 & 0.122 & 0.078 & 0.192 & 0.298 \\
\hline Log-pseudo likelihood & -67.013 & -64.921 & -62.679 & -65.841 & -57.671 & -50.118 \\
\hline
\end{tabular}

Note.- The table reports probit model estimates. Standard errors are robust to heteroskedasticity and are shown in parentheses. Omitted LENIENCY category is "the EC's 1996 Leniency". Omitted industry category is "wholesale and retail trade". Omitted market scope category is "national market". The source for these values is authors' calculations based on the decisions on 96 cartels by the European Commission and judgments of the Court of First Instance and the European Court of Justice for the period 1996-2012.

*** Significant at the 1 percent level.

** Significant at the 5 percent level.

* Significant at the 10 percent level. 

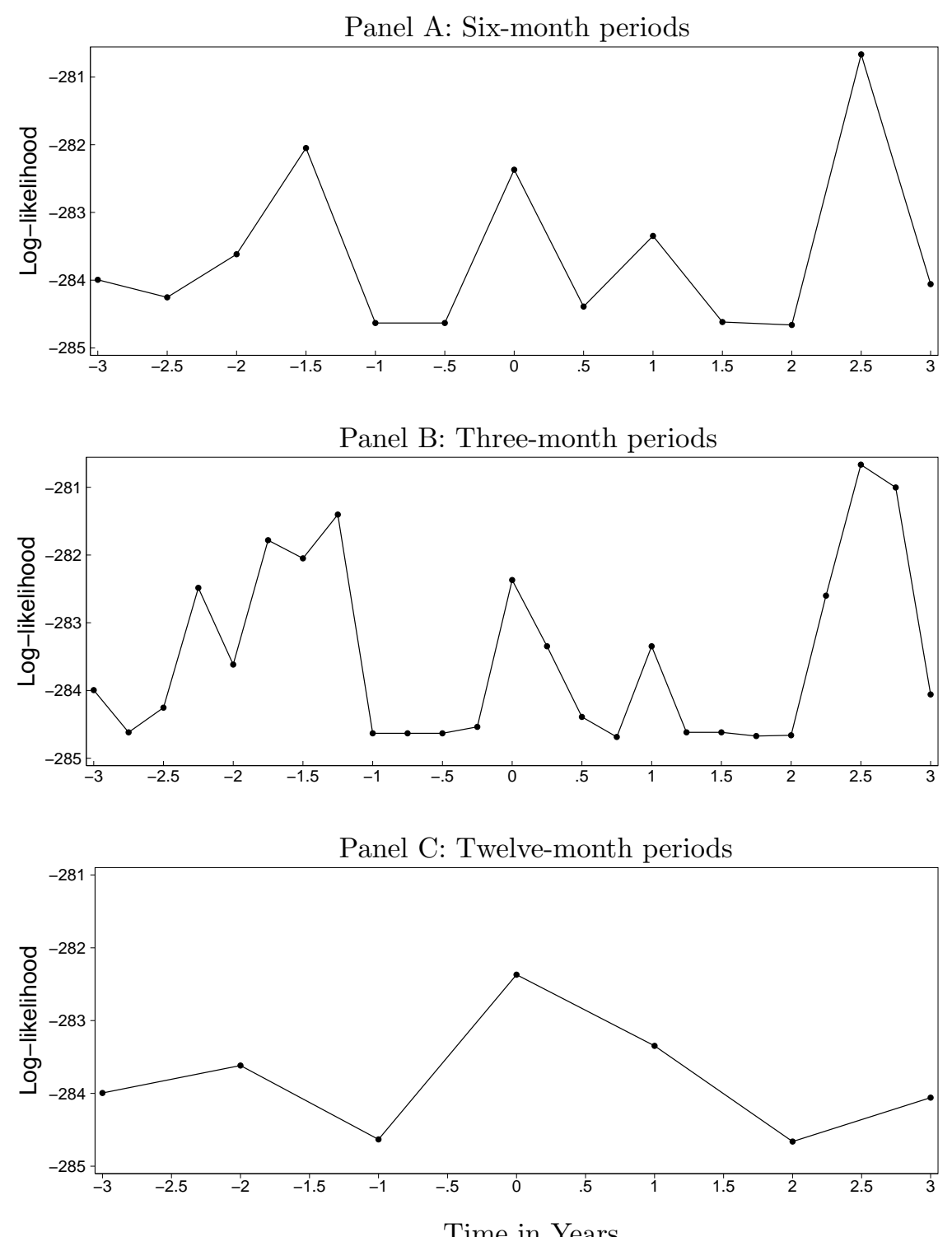

Figure 4. The EC's 2002 Leniency Program versus Placebo Interventions

Notes: Each point represents the maximized-likelihood of a Cox regression. The points located at zero on the horizontal axes correspond to the introduction of the EC's 2002 Leniency. The points to the left (resp. right) of zero correspond to placebo policies that predate (resp. postdate) the introduction of the EC's 2002 Leniency. 


\section{References}

[1] Akaike, Hirotugu (1974): "A New Look at The Statistical Model Identification," IEEE Transactions on Automatic Control, 19, pp. 716-23.

[2] Chang, Myong-Hun and Joseph E. Harrington, Jr. (2010): "The Impact of a Corporate Leniency Program on Antitrust Enforcement and Cartelization," working paper.

[3] Chen, Joe, and Joseph E. Harrington, Jr. (2007): "The Impact of the Corporate Leniency Program on Cartel Formation and the Cartel Price Path." In The Political Economy of Antitrust, edited by Vivek Ghosal and Johan Stennek. Elsevier.

[4] Cox, D. R. (1972): "Regression Models and Life-Tables (with Discussions)," Journal of Royal Statistical Society. Series B, 34, pp. 187-220.

[5] Cox, D. R. and Oakes, D. (1984): Analysis of Survival Data. London: Chapman and Hall.

[6] Ellis, Christopher J., and Wesley W. Wilson (2003): "Cartels, Price-Fixing, and Corporate Leniency Policy: What Doesn't Kill Us Makes Us Stronger," available at: http://darkwing.uoregon.edu/wwilson.

[7] European Commission (2004): "XXXIIIrd Report on Competition Policy 2003," ISSN 0259-3157.

[8] Fine, Jason P. and Robert J. Gray (1999): "A Proportional Hazards Model for the Subdistribution of a Competing Risk," Journal of the American Statistical Association, 94, pp. 496-509.

[9] Ghosal, Vivek, and Joseph Gallo (2001): “The Cyclical Behavior of the Department of Justice's Antitrust Enforcement Activity," International Journal of Industrial Organization, 19, pp. 27-54.

[10] Ghosal, Vivek, Joseph E. Harrington Jr., and Johan Stennek. (2007): "Issues in Antitrust Enforcement." In The Political Economy of Antitrust, Vivek Ghosal and Johan Stennek (Editors), Contributions to Economic Analysis Series, Elsevier: Amsterdam, 2007, pp. 1-23.

[11] Grambsch, Patricia M. and Terry M. Therneau (1994): "Proportional Hazards Tests and Diagnostics Based on Weighted Residuals," Biometrika, 81, pp. 515-26.

[12] Haltiwanger, John, and Harrington, Joseph E., Jr. (1991): "The Impact of Cyclical Demand Movements on Collusive Behavior," RAND Journal of Economics, 22, pp. 89-106.

[13] Hammond, Scott D. (2001): "When Calculating the Costs and Benefits of Applying for Corporate Amnesty, How Do You Put a Price Tag on An Individual's Freedom," Speech, The Fifteenth Annual National Institute on White Collar Crime.

[14] Hammond, Scott D. (2004): "Cornerstones of an Effective Leniency Program," Speech, ICN Workshop on Leniency Programs Sydney, Australia.

[15] Hammond, Scott D. (2010): "The Evolution of Criminal Antitrust Enforcement over the Last Two Decades," Speech,the 24th Annual National Institute On White Collar Crime.

[16] Harrington, Joseph E., Jr. (2004): "Optimal Cartel Pricing in the Presence of an Antitrust Authority," The RAND Journal of Economics, 35, pp. 651-73.

[17] Harrington, Joseph E., Jr. (2006a): "Corporate Leniency Programs and the Role of the Antitrust Authority in Detecting Collusion?", Competition Policy Research Center Discussion Paper, CPDP-18-E. 
[18] Harrington, Joseph E., Jr. (2006b): "How Do Cartels Operate?", in Foundations and Trends in Microeconomics, 2, pp. 1-105.

[19] Harrington, Joseph E., Jr. (2008): "Optimal Corporate Leniency Programs," Journal of Industrial Economics, 56, pp. 215-246.

[20] Harrington, Joseph E., Jr. and Myong-Hun Chang (2009): "Modeling the Birth And Death of Cartelswith An Application to Evaluating Competition Policy," Journal of European Economic Association, 7, pp. 1400-35.

[21] Harrington, Joseph E., Jr. and Andrzej Skrzypacz (2011): "Private Monitoring and Communication in Cartels: Explaining Recent Collusive Practices," American Economic Review, 101, pp. 1-25.

[22] Harrington, Joseph E., Jr. (2011): "Corporate Leniency with Private Information: The Push of Prosecution and the Pull of Pre-emption," Working papers, the Johns Hopkins University, Department of Economics 573 .

[23] International Competition Network (ICN) (2008): "Cartel Settlements," Report to the ICN Annual Conference, Kyoto, Japan.

[24] Kalbfleisch, J. D. and Ross L. Prentice (1980): The Statistical Analysis of Failure Time Data, New York: John Wiley \& Sons, Inc.

[25] Kaplow, L., and Shavell, S., (1994): "Optimal law enforcement with self-reporting of behavior," Journal of Political Economy, 102, pp. 583-606

[26] Kloub, Jindrich (2010): "Leniency as the Most Effective Tool in Combating Cartels," Sppech at Latin American Competition Forum.

[27] Laird, Nan (1978): "Nonparametric Maximum Likelihood Estimation of a Mixing Distribution," Journal of American Statistical Association, 73, pp. 805-11.

[28] Levenstein, Margaret C., and Valerie Y. Suslow (2011): "Breaking Up Is Hard to Do: Determinants of Cartel Duration," Journal of Law and Economics, 54, pp. 455-92.

[29] Lin, Y. (1991): "Goodness-of-Fit Analysis for the Cox Regression Model Based on a Class of Parameter Estimators," Journal of the American Statistical Association, 86, pp. 725-28.

[30] Lunn, Mary and Don R. McNeil (1995): "Applying Cox Regression to Competing Risks", Biometrics, 51, pp. 524-32.

[31] Mann, H. Michael (1966): "Seller Concentration, Barriers to Entry, and Rates of Return in Thirty Industries, 1950-1960," Review of Economics and Statistics, 48, pp. 296-307.

[32] Martin, Stephen (1979): "Entry Barriers, Concentration, and Profits," Southern Economics Journal, 46, pp. $471-88$.

[33] Meyer, Bruce D. (1990): "Unemployment Insurance and Unemployment Spells," Econometrica, 58, pp. 757-82.

[34] Miller, Nathan H. (2009): "Strategic Leniency and Cartel Enforcement," American Economic Review, 99, pp. $750-768$. 
[35] Motta, Massimo and Polo, Michele (2003): "Leniency Programs and Cartel Prosecution," International Journal of Industrial Organization, 21, pp. 347-79.

[36] Nambu, Jacquemin, A., T. and Dewez, I. (1981): “A Dynamic Analysis of Export Cartels: The Japanese Case", Economic Journal, 91, pp. 685-696.

[37] O'Brien, Ann (2008): "Cartel Settlements in the U.S. and EU: Similarities, Differences and Remaining Questions," Speech at the 13th Annual EU Competition Law and Policy Workshop Florence, Italy

[38] Organization for Economic Cooperation and Development (2002a): Fighting Hard Core Cartels: Harm, Effective Sanctions and Leniency Programmes.

[39] Organization for Economic Cooperation and Development (2002b): Hard Core Cartels - Harm and Effective Sanctions.

[40] (2012) "Leniency for Subsequent Applicants," DAF/COMP/WP3(2012)9.

[41] Pate, R. Hewitt (2004): "International Anti-Cartel Enforcement," Speech, International Competition Network Cartels Workshop, Sydney, Australia, November 21, 2004.

[42] Organization for Economic Cooperation and Development (2003): Hard Core Cartels. Recent Progress and Challenges Ahead.

[43] Perperoglou, Aris, Saskia le Cessie, and Hans C. van Houwelingen (2005): "Reduced-Rank Hazard Regression for Modelling Non-Proportional Hazards", Statistics in Medicine, 25, pp. 2831-2845.

[44] Porter, R. H. (1985): "On the Incidence and Duration of Price Wars," Journal of Industrial Economics, 33 , pp. 415-26.

[45] Rey, Patrick. (2003): "Towards a Theory of Competition Policy," In M. Dewatripont, L.P. Hansen, and S.J. Turnovsky, eds., Advances in Economics and Econometrics: Theory and Applications. Cambridge, UK: Cambridge University Press, 2003.

[46] Rosenbaum, Paul R., and Donald B. Rubin (1983): "The Central Role of the Propensity Score in Observational Studies for Causal Effects," Biometrika, 70, pp. 41-55.

[47] Russo, Francesco, Maarten Pieter Schinkel, Andrea Günster, Martin Carree (2010): European Commission Decisions on Competition — Economic Perspectives on Landmark Antitrust and Merger Cases, pp. 26-107. Cambridge: Cambridge University Press.

[48] Schoenfeld, D. (1982): "Partial Residuals for The Proportional Hazards Regression Model," Biometrika, 69, pp. 239-41.

[49] Selten, Reinhard (1973): "A Simple Model of Imperfect Competition, Where 4 are Few and 6 are Many," International Journal of Game Theory, 2, 141-201.

[50] Spagnolo, Giancarlo (2008): " "Leniency and Whistleblowers in Antitrust," In P. Buccirossi, ed., Handbook of Antitrust Economics. Cambridge, Mass.: MIT Press, 2008.

[51] Spratling, Gary R. (1999): "Making Companies an Offer They Shouldnt Refuse," Speech, Bar Association of the District of Columbias 35th Annual Symposium on Associations and Antitrust, Washington, DC, February 16, 1999. 
[52] Symeonidis, George (2002): The Effects of Competition: Cartel Policy and the Evolution of Strategy and Structure in British Industry. Cambridge, Mass.: MIT Press.

[53] Vasconcelos, H. (2008): "Sustaining Collusion in Growing Markets," Journal of Economics and Management Studies, 17, pp. 973-1010.

[54] Zhou, Jun (2012a): "Evaluating Leniency with Missing Information on Undetected Cartels: Exploring Time-Varying Policy Impacts on Cartel Duration," SFB TR 15 Discussion Paper No. 353, available at SSRN: http://ssrn.com/abstract $=1798424$

[55] Zhou, Jun (2012b): "Cartel Duration and Endogenous Private Monitoring and Communication: An Instrumental Variables Approach," SFB TR 15 Discussion Paper No. 369, available at SSRN: http://ssrn.com/abstract $=1985798$ 